\title{
The impact of exercise training on calf pump function, muscle strength, ankle range of motion, and health-related quality of life in patients with chronic venous insufficiency at different stages of severity: a systematic review
}

\section{O impacto do treinamento físico na função da bomba da panturrilha, força muscular, amplitude de movimento do tornozelo e qualidade de vida relacionada à saúde em diferentes estágios de gravidade da insuficiência venosa crônica: uma revisão sistemática}

\author{
Keity Lamary Souza Silva ${ }^{1}$ (D), Eduardo Augusto Barbosa Figueiredo ${ }^{1}$ (D), Cíntia Pimenta Lopes ${ }^{1}$ (D), \\ Marcus Vinicius Accetta Vianna² (D), Vanessa Pereira Lima, ${ }^{1,3}$ (D), Pedro Henrique Scheidt Figueiredo ${ }^{1,3}$ (D), \\ Henrique Silveira Costa ${ }^{1,3}$ (D)
}

\begin{abstract}
Exercise training (ET) is an important tool in the management of patients with chronic venous insufficiency (CVI). The objective of this article was to discuss the effects of ET on the calf pump, functional parameters, and quality of life of patients with mild and advanced CVI. A systematic review was conducted and eleven studies were included. In patients with mild CVI, ET was effective for improving venous reflux, muscle strength, ankle range of motion, and quality of life. In advanced CVI patients, ET increased ejection fraction, reduced residual volume fraction, and improved muscle strength and ankle range of motion, but did not change venous reflux indices or quality of life. It is concluded that $\mathrm{ET}$ is effective for improving calf pump function, muscle strength, and ankle range of motion in CVI. In patients with mild CVI, additional benefits were observed in quality of life.
\end{abstract}

Keywords: venous insufficiency; exercise; muscle strength; articular range of motion; quality of life.

\begin{abstract}
Resumo
O treinamento físico é uma importante ferramenta no tratamento de pacientes com insuficiência venosa crônica. O objetivo foi discutir os efeitos do tratamento físico na bomba da panturilha, os parâmetros funcionais e a qualidade de vida de pacientes com insuficiência venosa crônica leve e avançada. Uma revisão sistemática foi realizada, e 11 estudos foram incluídos. Na insuficiência venosa crônica leve, o treinamento físico foi eficaz na melhora do refluxo venoso, da força muscular, da amplitude de movimento do tornozelo e da qualidade de vida. Na insuficiência venosa crônica avançada, o treinamento físico aumentou a fração de ejeção, reduziu a fração de volume residual e melhorou a força muscular e amplitude de movimento do tornozelo, sem alterações nos índices de refluxo venoso e na qualidade de vida. Conclui-se que o treinamento físico é eficaz na melhoria da bomba da panturrilha, da força muscular e da amplitude de movimento do tornozelo na insuficiência venosa crônica. Em pacientes com insuficiência venosa crônica leve, foram encontrados benefícios adicionais na qualidade de vida.
\end{abstract}

Palavras-chave: insuficiência venosa; exercício físico; força muscular; amplitude de movimento articular; qualidade de vida.

How to cite: Silva KLS, Figueiredo EAB, Lopes CP, et al. The impact of exercise training on calf pump function, muscle strength, ankle range of motion, and health-related quality of life in patients with chronic venous insufficiency at different stages of severity: a systematic review. J Vasc Bras. 2021;20:e20200125. https://doi.org/10.1590/1677-5449.200125

${ }^{1}$ Universidade Federal dos Vales do Jequitinhonha e Mucuri - UFVJM, Faculdade de Ciências Biológicas e da Saúde, Departamento de Fisioterapia, Diamantina, MG, Brasil.

${ }^{2}$ Universidade Federal dos Vales do Jequitinhonha e Mucuri - UFVJM, Faculdade de Medicina, Diamantina, MG, Brasil.

${ }^{3}$ Universidade Federal dos Vales do Jequitinhonha e Mucuri - UFVJM, Programa de Pós-graduação em Reabilitação e Desempenho Funcional, Diamantina, MG, Brasil. Financial support: None

Conflicts of interest: No conflicts of interest declared concerning the publication of this article.

Submitted: July 28, 2020. Accepted: August 24, 2020

The study was carried out at Universidade Federal dos Vales do Jequitinhonha e Mucuri (UFVJM), Diamantina, MG, Brazil.

Copyright(C 2021 The authors. This is an Open Access article distributed under the terms of the Creative Commons Attribution License, which permits unrestricted use, distribution, and reproduction in any medium, provided the original work is properly cited. 


\section{INTRODUCTION}

Chronic venous insufficiency (CVI) is characterized by abnormal lower limb venous system function. It has a high prevalence and morbidity in Brazil ${ }^{1,2}$ and worldwide, ${ }^{3}$ with considerable economic impact due to disability. ${ }^{4}$ Previous studies have estimated that 5 to $30 \%$ of the adult population have signs or symptoms of the disease and CVI can therefore be considered a serious public health problem. ${ }^{5,6}$

Chronic venous insufficiency has a broad spectrum of clinical manifestations, ranging from telangiectasias and reticular veins to active and recurrent venous ulcers. $^{7}$ The pathophysiologic mechanism of the disease is multifactorial ${ }^{8}$ and may be due to mechanical obstruction of the venous flow (superficial and deep), valve incompetence, or dysfunction of the calf muscle pump. ${ }^{8-10}$ There is an imbalance of blood flow in the lower limbs that compromises venous return, ${ }^{2}$ resulting in increased venous pressure. ${ }^{10}$ Consequently, many studies have shown the harmful consequences of CVI, ${ }^{1}$ such as impaired work activities, poor performance in daily activities, and decline in emotional health and self-esteem. ${ }^{1,6,11}$ It has also been linked to worse health-related quality of life ${ }^{12,13}$ due to pain, leg tiredness, edema and, in advanced cases, ulcerations. ${ }^{2,9}$ In this scenario, exercise training (ET) emerges as an important tool in the conservative management of patients. ${ }^{14}$ Several studies have reported that ET prevents the progression and complications of venous disease, reduces symptoms and improves health-related quality of life. ${ }^{5,15}$

However, data about the benefits of ET is scattered and needs to be systematically discussed to increase knowledge about exercise prescription in these patients. Two well-designed systematic reviews were addressed to verify the effect of ET on patients with CVI. One ${ }^{16}$ demonstrated that ET is effective in improving some parameters of calf pump function, such as the ejection fraction, but not the ankle range of motion or healing of venous leg ulcers. However, the review included studies with patients at different stages of the disease, i.e., with or without venous leg ulcers. Another review ${ }^{4}$ included studies that only encompassed patients without venous leg ulcers. Considering the heterogeneous clinical, functional, and health-related quality of life expression of mild patients compared to those with skin changes, it is necessary to verify the effect of ET at different stages of the disease. Therefore, the present study aimed to systematically discuss the effects of ET on variables related to calf pump function, functional parameters, and health-related quality of life in patients with mild and advanced CVI.

\section{METHODS}

\section{Study design}

This systematic review aimed to verify the impact of ET on calf pump function, functional parameters, and health-related quality of life of patients with CVI. The study was registered on the PROSPERO database (CRD42020159204) and edited following the guidelines of the Preferred Reporting Items for Systematic Reviews and Meta- Analyses (PRISMA) statement. ${ }^{17}$

\section{Search strategy and study selection}

Potential studies were identified using a systematic search strategy. The databases MEDLINE, Web of Science, Cumulative Index to Nursing and Allied Health Literature (CINAHL), Latin American \& Caribbean Health Sciences Literature (LILACS), Scopus, and Physiotherapy Evidence Database (PEDro) were searched for relevant studies, with no date restrictions, from inception up to May 2020. Searches were conducted independently by 2 authors (CPL and HSC) from May to June of 2020. Disagreements were resolved by a third reviewer (KLSS). Search terms included words related to chronic venous insufficiency, venous leg ulcer, and exercise training. The following strategy was used for the PubMed search: ("venous insufficiency" OR" venous disease" OR "chronic venous disease") AND ("exercise" OR "physiotherapy" OR "physical therapy") and was modified to suit each database.

\section{Eligibility criteria}

The eligibility criteria were studies that a) evaluated patients diagnosed with CVI; b) performed ET in patients with CVI; and c) used calf pump parameters, functional variables, and health-related quality of life as outcomes. Exclusion criteria were review studies, articles in duplicate, animal studies, and those that did not fit the objective of this review. Papers dealing with post-thrombotic syndrome, that combined nonconservative treatment techniques, and/or used other modalities of physical therapy, such as balneotherapy and manual therapy, were also excluded.

\section{Quality assessment}

Quality was assessed using the PEDro Scale, described in the Physiotherapy Evidence Database (www.pedro.org.au). This scale consists of 11 items and was developed to classify the methodological quality (internal validity and statistical information) of randomized clinical trials. Studies not validated by the PEDro scale were evaluated by the authors.

\section{Outcomes and data analysis}

The following data were extracted from the included articles: author, publication year, characteristics of 
the sample (both experimental and control group, if applicable), treatment, and changes in the parameters evaluated before and after exercise training. Patients with CVI were stratified according to CEAP class, ${ }^{7}$ as follows: telangiectasias or reticular veins $(\mathrm{C} 1)$; varicose veins $(\mathrm{C} 2)$; recurrent varicose veins $(\mathrm{C} 2 \mathrm{r})$; edema (C3); changes to skin and subcutaneous tissue secondary to CVI (C4); pigmentation or eczema (C4a); lipodermatosclerosis or atrophie blanche $(\mathrm{C} 4 \mathrm{~b})$; corona phlebectatica $(\mathrm{C} 4 \mathrm{c})$; healed venous ulcer $(\mathrm{C} 5)$; active venous ulcer (C6); or recurrent active venous ulcer (C6r). Due to the differences in clinical expression with functional impact, studies were stratified as investigating mild CVI (CEAP class less than or equal to 3 ) or advanced CVI (with skin abnormalities and venous ulcer; CEAP class greater than or equal to 4). When a study encompassed a wide variety of CEAP classes, the one with the largest sample size was considered for stratification.

The primary outcome measure was intragroup or intergroup difference in calf pump parameters, functional variables, and health-related quality of life.

\section{RESULTS}

\section{Flow of papers through the review}

The electronic search strategy identified 1,186 studies, but $525(42 \%)$ of these were duplicates. After screening titles and abstracts, 626 papers were excluded. Most of them were review studies, did not perform ET, or used a sample without CVI. After reading the full texts, 24 articles were excluded for failing to fit the objectives of the present review. A total of 11 articles were included in the present review. Figure 1 outlines the flow of papers through the review.

\section{Participants}

Five studies investigated the effect of ET on patients with mild CVI. Three of these studies $(60 \%)$ each analyzed a single group of patients, one (20\%) compared the ET group with usual care, and another compared ET against ET associated with intermittent pneumatic compression. The number of sessions ranged from 10 to 48 . The mean quality assessment score for the studies included was 2.8, ranging from 1 to 7 .

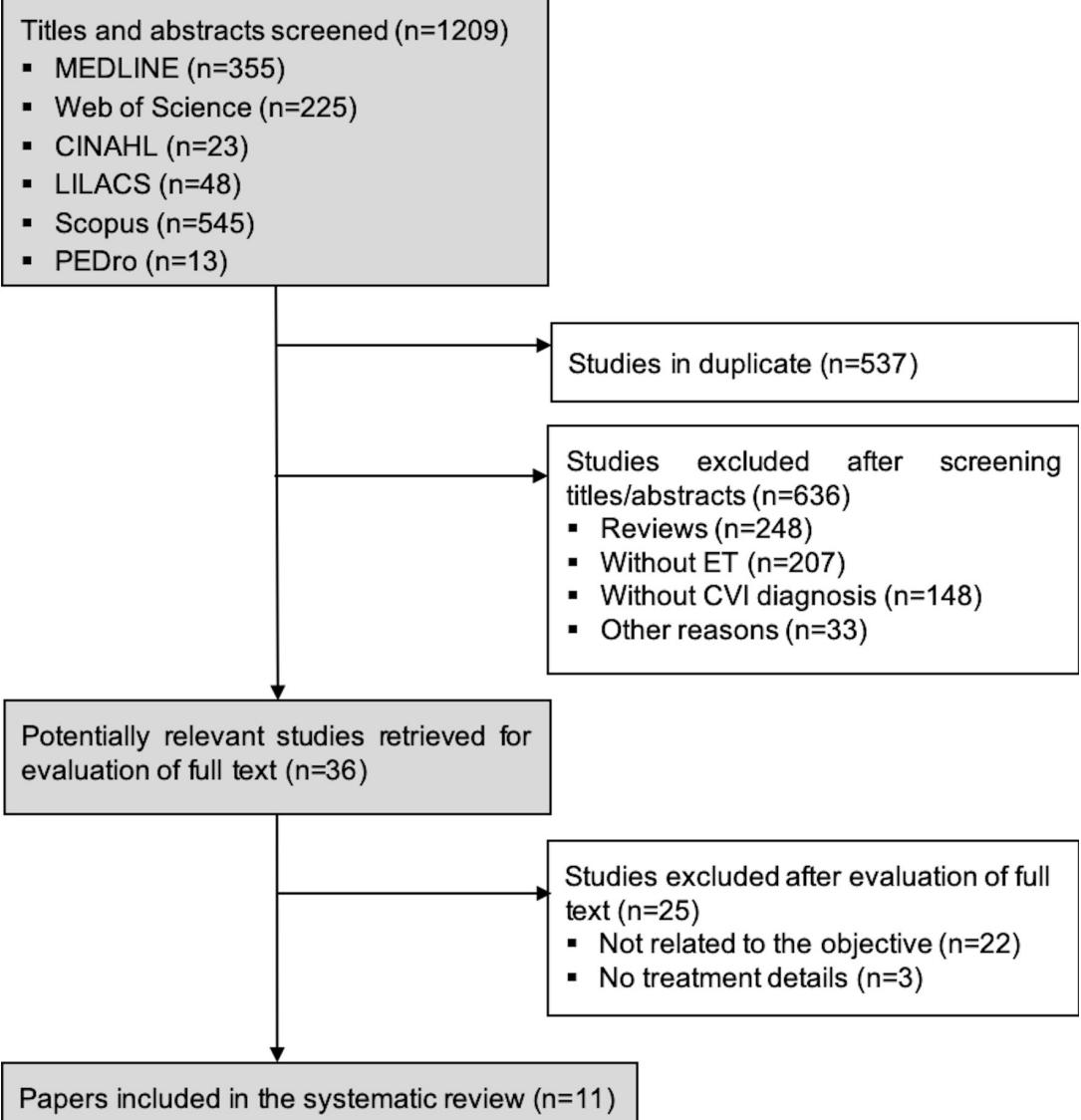

Figure 1. The PRISMA flow diagram of papers through the review. CVI: chronic venous insufficiency; ET: exercise training; MEDLINE: Medical Literature Analysis and Retrieval System Online; CINAHL: Cumulative Index to Nursing and Allied Health Literature; LILACS: Latin American \& Caribbean Health Sciences Literature. 
Another seven studies aimed to verify the impact of ET on calf pump function, functional parameters, and health-related quality of life of patients with CVI with skin changes or venous leg ulcers. Three of these studies, (44\%) analyzed a single group each, two $(28 \%)$ had a group given usual care combined with compression as control, in one study (14\%) the control group was kept on usual care, and in one study $(14 \%)$ the control group was instructed to perform exercises at home, without supervision. The number of sessions ranged from 18 to 48 . The mean score for methodological quality was 3.6 (ranging from 1 to 7 ).

\section{Outcomes}

Nine studies demonstrated the effect of ET on calf pump function, four in mild CVI and five in patients with advanced CVI. The variables ejection fraction, residual volume fraction, residual volume, ejected volume, venous volume, venous filling time, and blood flow were used in the studies included and defined according to Jull et al. ${ }^{18}$

The functional parameters evaluated included those related to ankle range of motion and strength. Ankle range of motion after ET was assessed by goniometry in 4 studies, two in mild patients, ${ }^{11,12}$ and two in patients with advanced CVI..$^{19,20}$ Strength was tested with isokinetic dynamometry in three studies, one in mild CVI ${ }^{11}$ and two in CVI with skin changes. ${ }^{21,22}$ The variables used were the peak torque, peak initial torque, the ratio between peak torque and body weight, and ankle total work.

Four studies evaluated the impact of exercise on health-related quality of life in patients with CVI. Two of them in mild patients ${ }^{11,12}$ and two in patients with advanced CVI. ${ }^{13,21}$ The questionnaires used in the studies were both generic (the Short-form Health Survey [SF-36] and the EuroQol 5 Dimensions [EQ-5D]), and specific (the Aberdeen Varicose Veins Questionnaire [AVVQ] and the Chronic Venous Insufficiency Questionnaire [CIVIQ]).

\section{Outcomes in patients with mild CVI}

The impact of ET on calf pump function in patients with mild CVI was verified in four studies. ${ }^{11,14,23,24}$ All of them demonstrated a significant improvement in venous reflux in terms of reduced venous refilling time. Improvements were also demonstrated in venous volume $^{14}$ and blood flow. ${ }^{23}$

With regard to evaluation of functional parameters, two studies verified the effect of ET on the ankle range of motion ${ }^{11,12}$ and one ${ }^{11}$ verified the impact of ET on muscle strength. Ankle range of motion significantly increased after ET in both studies. Likewise, ET was also effective for increasing peak torque, peak initial torque, and total work ( $\mathrm{p}<0.001$ for all outcomes).
Improvements in health-related quality of life after ET were demonstrated in both studies that analyzed this outcome, ${ }^{11,12}$ according to the SF-36 ( $<<0.05$ in all domains), the AVVQ ( $p<0.05$ in all domains), and the EQ-5D ( $\mathrm{p}=0.001)$. The main results of the effects of ET on the variables analyzed in patients with mild CVI are shown in Table 1.

\section{Outcomes in patients with advanced CVI}

Five studies demonstrated the effects of ET on variables related to calf pump function. All articles that evaluated the ejection fraction $(n=4)^{18,20-22}$ showed a significant increase in this parameter after ET. In addition, four out of five studies ${ }^{20-22,24}$ showed that ET reduced the residual volume fraction in patients with advanced CVI. None of the studies found changes in the venous volume, ${ }^{18,21,22}$ venous filling index,,$^{18,20-22}$ ejected volume, ${ }^{18,21}$ or residual volume. ${ }^{18}$

Improvements in ankle range of motion were detected in two studies, ${ }^{19,20}$ both demonstrating significant increases in this parameter after ET. Additionally, one study ${ }^{19}$ demonstrated that the increase in ankle range of motion was observed in groups that performed supervised and non-supervised ET, but that the increase was greater in the group performing supervised ET. Changes in muscle strength were demonstrated in one study, ${ }^{21}$ in terms of a significant increase in the ratio between peak torque and body weight, whereas in another study peak torque and total work did not change after ET. ${ }^{22}$

Regarding health-related quality of life, one study found significant improvements in this outcome according to the CIVIQ ( $<<0.05),{ }^{13}$ while another ${ }^{21}$ did not find changes when using the AVVQ and CIVIQ questionnaires and the physical function items of the SF-36. Details of the results found by the studies that analyzed patients with advanced CVI are shown in Table 2.

\section{DISCUSSION}

ET may have positive effects on the neuromuscular systems of patients with CVI, due to improvements in muscle structure and reduction of blood reflux and edema. ${ }^{6}$ The possible effects of ET on calf pump function, muscle strength, ankle range of motion, and health-related quality of life should be systematically discussed according to the severity of CVI. Therefore, the main findings of the present systematic review were that ET: 1) improves venous reflux, ankle range of motion, muscle strength, and health-related quality of life in patients with mild CVI and;2) improves ejection fraction, residual volume, ankle range of motion, and muscle strength in patients with advanced CVI and skin changes or leg ulcers, without changing 
Table 1. The effect of exercise training in management of patients with mild chronic venous insufficiency $(n=5)$.

\begin{tabular}{|c|c|c|c|c|c|}
\hline Study & Population & Intervention & Comparison & Outcomes & $\begin{array}{l}\text { PEDro } \\
\text { Score }\end{array}$ \\
\hline Hartmann et al..$^{14}$ & $\begin{array}{l}12 \text { patients } \\
(\text { CEAP C2) with } \\
\text { varicose veins in } \\
\text { both extremities. }\end{array}$ & $\begin{array}{l}\text { 24-weeks of physiotherapy, } \\
\text { twice a week, } 60 \text { minutes } \\
\text { each session. The sessions } \\
\text { consisted of bathing and } \\
25 \text { minutes of exercise for } \\
\text { muscle and joint activation } \\
\text { with compression stockings. } \\
\text { Additionally, home-based } \\
\text { exercises once a day for } \\
15 \text { minutes, wearing } \\
\text { compression stockings }\end{array}$ & Usual care $(n=12)$ & $\begin{array}{l}\text { In the experimental group, } \\
\text { ET reduced venous capacity } \\
(p<0.005) \text { and venous refilling } \\
\text { time in the lower limbs } \\
(p<0.001) \text {. } \\
\text { There were no changes in the } \\
\text { control group. }\end{array}$ & $4 / 10$ \\
\hline Zajkowsk et al. ${ }^{24}$ & $\begin{array}{l}11 \text { patients } \\
\text { (mean age } 60 \\
\text { years), comprising } \\
\text { CEAP C2 }(n=6) \text { and } \\
\text { C } 4 \text { and } C 5(n=5) \text {. }\end{array}$ & $\begin{array}{l}18 \text { sessions ( } 1 \text { h per session), } \\
2-3 \text { times a week, of calf } \\
\text { muscle strengthening with } \\
\text { compression stockings. }\end{array}$ & Single group. & $\begin{array}{l}\text { For patients with CEAP C2: } \\
\text { venous reflux decreased. }\end{array}$ & $1 / 10$ \\
\hline Leal et al. ${ }^{12}$ & $\begin{array}{l}10 \text { patients } \\
(43.1 \pm 9.4 \text { years, } \\
\text { CEAP C } 2-C 3)\end{array}$ & $\begin{array}{l}10 \text { sessions of } 60 \text { minutes, } \\
3 \text { times a week. Each session } \\
\text { comprised therapeutic } \\
\text { exercises (stretching the } \\
\text { lower limbs, strengthening } \\
\text { the calf with } 2-3 \text { sets of } \\
10 \text { repetitions), walking on } \\
\text { the treadmill for } 10 \text { minutes } \\
\text { and manual lymph drainage. }\end{array}$ & Single group. & $\begin{array}{l}\text { ET increased range of motion } \\
\text { in dorsiflexion, plantar flexion, } \\
\text { adduction, and abduction } \\
\text { ( } p<0.05 \text { for all) and improved } \\
\text { quality of life in all domains of } \\
\text { the SF- } 36 \text { and the Aberdeen } \\
\text { Varicose Veins Questionnaire } \\
\text { (AVVQ) ( }<<0.05 \text { for all } \\
\text { domains). }\end{array}$ & $1 / 10$ \\
\hline Ercan et al. ${ }^{11}$ & $\begin{array}{l}27 \text { patients } \\
(48 \pm 9 \text { years, CEAP } \\
\text { C3-C } 4)\end{array}$ & $\begin{array}{l}\text { 12-weeks of ET, } 3 \text { days per } \\
\text { week. The ET comprised } \\
3 \text { sets of 10rep of range } \\
\text { of motion and stretching } \\
\text { exercises, Theraband } \\
\text { exercises, isokinetic exercise. } \\
\text { Additionally, stability exercise } \\
\text { on a balance board ( } 10 \\
\text { min), walking on treadmill } \\
\text { ( } 60 \% \text { HR max, } 20 \text { min) and } \\
\text { intermittent pneumatic } \\
\text { compression ( } 20 \text { min). }\end{array}$ & Single group. & $\begin{array}{l}\text { Improved range of motion in } \\
\text { dorsiflexion }(p=0.018) \text { and } \\
\text { plantar flexion }(p=0.004) \text {, } \\
\text { increased peak torque, peak } \\
\text { initial torque, and total } \\
\text { dorsiflexion and plantar flexion } \\
\text { work ( } p=0.001 \text { for all), health- } \\
\text { related quality of life by EQ-5D } \\
(p=0.001) \text { and venous return } \\
\text { time }(p=0.001) \text {. }\end{array}$ & $1 / 10$ \\
\hline Elsisi et al. ${ }^{23}$ & $\begin{array}{l}25 \text { patients with } \\
\text { bilateral varicose } \\
\text { veins } \\
(43.88 \pm 6.73 \text { years, } \\
\text { CEAP C2) }\end{array}$ & $\begin{array}{l}3 \text { months of ET, including } \\
\text { gluteal and quadriceps } \\
\text { isometric exercises, } \\
\text { active hip and knee } \\
\text { flexion/extension, ankle } \\
\text { dorsiflexion/ plantar flexion, } \\
\text { and straight leg rising in } \\
\text { conjunction with use of } \\
\text { an intermittent pneumatic } \\
\text { compression device. }\end{array}$ & $\begin{array}{l}\text { ET associated with } \\
\text { tip-toe strengthening, } \\
\text { ergometer exercise } \\
\text { with elastic } \\
\text { compression stockings } \\
\text { ( } n=25,44.52 \pm 6.23 \text { years). }\end{array}$ & $\begin{array}{l}\text { Both groups had improvements } \\
\text { in maximum blood flow, mean } \\
\text { blood flow; and venous refilling } \\
\text { time }(p<0.05) \text {. Improvements } \\
\text { in the experimental group were } \\
\text { significantly higher than in the } \\
\text { control group. }\end{array}$ & $7 / 10$ \\
\hline
\end{tabular}

venous reflux parameters. These findings reinforce the importance of ET in clinical management of all stages of CVI, mainly by increasing muscle strength, ankle range of motion, and calf pump function. However, at more advanced stages, ET does not seem to be effective in reducing venous reflux and there is no evidence to support improvements in health-related quality of life after ET in these patients.

Muscle dysfunction is identified as one of the etiological factors of CVI. ${ }^{25}$ Consequently, in mild
CVI, ET emerges as a useful tool for control of the signs and symptoms of the disease as well as for prevention of disabilities due to reduction of hydrostatic pressure during movement. ${ }^{6}$ Exercise training based on strengthening the calf muscles seems to be able to stimulate muscle strength. Furthermore, when associated with compression techniques, ET facilitates improvement of venous reflux. ${ }^{24}$ The possible mechanism behind this change is activation of the deep venous system, increasing its venous capacity, and 
Table 2. The effect of exercise training in management of patients with advanced chronic venous insufficiency $(n=7)$.

\begin{tabular}{cll}
\hline \multicolumn{1}{c}{ Study } & \multicolumn{1}{c}{ Population } & \multicolumn{1}{c}{ Intervention } \\
\hline${\text { Yang et al. }{ }^{22}}^{\text {20 patients with }}$ & $\begin{array}{l}\text { 6 weeks of ET comprising } \\
\text { venous leg ulcers. } \\
\text { tip-toe exercises associated } \\
\text { Median age of } 68 \\
\text { (range: 34 to } 88) \\
\text { years. } \\
\text { exercises. }\end{array}$ \\
Padberg et al. ${ }^{21}$ & $\begin{array}{l}\text { Patients with skin } \\
\text { changes } \\
\text { (n=17, mean age } \\
\text { of 71 years, CEAP } \\
\text { C4- C6) }\end{array}$ & $\begin{array}{l}\text { 6 months of stockings } \\
\text { combined with lower limb } \\
\text { and trunk stretching and } \\
\text { strengthening, with active } \\
\text { gravity strengthening and } \\
\text { resistive weights in two } \\
\text { sessions per week (1 hour } \\
\text { duration). }\end{array}$ \\
& &
\end{tabular}

\begin{tabular}{|c|c|c|}
\hline Zajkowsk et al. ${ }^{24}$ & $\begin{array}{l}11 \text { patients (mean } \\
\text { age } 60 \text { years), } \\
\text { comprising CEAP C2 } \\
(n=6) \text { and } C 4 \text { and } C 5 \\
(n=5) \text {. }\end{array}$ & $\begin{array}{l}18 \text { sessions ( } 1 \text { h per session), } \\
2-3 \text { times a week, of calf } \\
\text { muscle strengthening with } \\
\text { compression stockings. }\end{array}$ \\
\hline Jull et al. ${ }^{18}$ & $\begin{array}{l}20 \text { patients } \\
(54.6 \pm 19.9 \text { years }) \\
\text { with venous leg } \\
\text { ulcers. }\end{array}$ & $\begin{array}{l}\text { 12-week home-based } \\
\text { progressive resistance exercise } \\
\text { program using heel rises in } \\
\text { addition to compression. }\end{array}$ \\
\hline
\end{tabular}

Szewczyk et al. ${ }^{19}$ Patients with venous 9-week supervised program leg ulcers $(n=16,77.2 \pm 7.66$ years, CEAP (6).

$\begin{array}{rl}\text { O'Brien et al. }^{20} & 4 \text { patients } \\ & (66 \pm 6 \text { years) with } \\ & \text { active venous } \\ & \text { ulceration. }\end{array}$

Kravtsov et al..$^{13} 22$ patients with varicose veins, CEAP C3 $(n=6)$ and C4 $(n=16)$.

\section{of exercises (circular foot} movements, lifting the body weight while standing on the toes, alternate performance of foot dorsiflexion and plantar flexion). The exercises were performed 3 times a day, in series of 15 repetitions. Moreover, all patients walked $3 \mathrm{~km}$ daily and additionally exercised on training bikes.

12 weeks of high-
compression bandaging, leg
elevation and performing leg

Usual care $(n=3,63.6 \pm 20$ years $)$ and/or ankle exercises. exercise without supervision CEAP (6).

(n)

Single group.

Usual care in addition to compression $(n=19,53.3 \pm 19.9$ years $)$.

Performance of $(n=16,72.3 \pm 10.13$ years,

60 days of specially designed Single group. complex of 7 exercises intended to strengthen the posterior muscle group of the lower legs and correct the step cycle.
Usual care in addition compression 70 years, CEAP C4- C6).

4- C6).
Increase in ejection fraction and decrease in residual volume fraction $(p<0.05)$. No changes in venous volume, venous filling index, peak torque, or total work

Experimental group improved $5 / 10$ residual volume fraction $(p<0.029)$, mean ejection fraction $(p<0.026)$, isokinetic peak torque/body weight at both slow speed $(p<0.05)$, and fast speed $(p<0.03)$. No changes in venous filling index, venous volume, or ejected volume. No changes were observed health-related quality of life (according to the Aberdeen Varicose Vein Survey, the CIVIQ, and the physical function items of the SF-36).

For CEAP C4-C5 patients: residual volume fraction decreased $(p<0.05)$.

Experimental group improved $7 / 10$ ejection fraction $(p<0.05)$. There were no significant differences between groups in venous volume, ejection volume, venous filling index, residual volume, or residual volume fraction.

Experimental group increased ankle joint mobility in dorsiflexion and plantar flexion ( $p<0.05$ for both). The control group also increased ankle joint mobility in dorsiflexion and plantar flexion ( $p<0.05$ for both), but improvements were greater in the experimental group $(p<0.05)$.

Experimental group increased ejection fraction $(p=0.03)$ and decreased residual volume fraction $(p=0.03)$. No changes in the venous filling index $(p=0.17)$. There were also changes in ankle range of motion ( $\mathrm{p}=0.01$ ).

ET improved health-related quality of life by CIVIQ 
reducing venous hypertension. ${ }^{14,19,23}$ This reduction in venous hypertension, caused by the combination of exercise and venous compression, stimulates production of nitric oxide, a potent neuromodulator of venous tone, with inhibition of platelet aggregation and neutrophil adhesion, which are essential elements of hypoxia injury. ${ }^{23}$

The combination of increased muscle strength with reduced venous reflux can improve the ankle range of motion, since both mechanisms will lead to a reduction in edema. Increased health-related quality of life is therefore expected and was found by all studies that addressed this variable, since ET is effective in reducing the signs and symptoms of CVI.

In patients with advanced CVI, ET seems to improve muscle strength, enhancing muscle contraction and increasing peak calf muscle torque. We believe that exercise can reduce the morphological changes present in patients with CVI, such as atrophy of the gastrocnemius muscle, muscle denervation, and inflammatory cell proliferation..$^{26,27}$ Additionally, the present study demonstrated that ET is able to improve calf muscle pump function, especially residual volume fraction, ${ }^{21,24}$ ejection fraction, ${ }^{18,20,21}$ and venous volume. ${ }^{24}$ However, the venous reflux indices do not change after $\mathrm{ET}^{18,21}$ because there is no significant modification to the venous wall structure capable of provoking improvement in venous reflux rates. ${ }^{18,20}$ In fact, it is well established that the clinical improvement in patients with CVI is related to greater venous blood ejection and improved venous function. ${ }^{18}$ After ET, ejection of greater blood volumes, with consequent drop in venous pressure, is to be expected because of muscle strengthening. ${ }^{21}$ However, in advanced CVI, there is no improvement in venous function. ${ }^{18}$ Therefore, venous reflux and venous hypertension remain, leading to blood stasis in the lower limbs and impairing the return of blood to the heart against gravity. ${ }^{3}$

Ankle range of motion is related to CVI severity ${ }^{28}$ and to calf pump function parameters such as ejection fraction and residual volume. ${ }^{29}$ Since the patients showed significant improvement in calf pump function after ET, it is to be expected that range of motion would also increase.

Regarding changes in health-related quality of life, the results of the two studies that measured it in these patients were inconsistent. While one study found a significant improvement in health-related quality of life assessed by CIVIQ after ET, a clinical trial showed no improvement in the health-related quality of life evaluated by Aberdeen, CIVIQ, and SF-36 questionnaires. However, it is woth noting that the SF-36 is a generic questionnaire and does not cover the peculiarities of this disease, while the two specific questionnaires target patients with mild CVI. ${ }^{30}$ Therefore, the effect of ET on health-related quality of life in severe CVI remains unknown and we believe that further studies with questionnaires aimed at this specific population are desirable.

The present study has some limitations. Many studies had low quality scores, mainly due to absence of control groups. Additionally, many studies also combined compression techniques with ET, making it difficult to verify the effect of each treatment technique in isolation. One strength of the present review is that it included studies in all languages with no date restrictions, demonstrating the effect of ET at different stages of CVI severity.

\section{CONCLUSION}

Exercise training is a valuable tool for treatment of mild and advanced CVI conditions, since it promotes hemodynamic and musculoskeletal improvements that improve functionality. In individuals with mild CVI, there are also benefits in health-related quality of life parameters, while in the most severe cases there is no evidence to support improvement in venous reflux or health-related quality of life.

\section{REFERENCES}

1. Santos RFFN, Porfírio GJM, Pitta GBB. A diferença na qualidade de vida de pacientes com doença venosa crônica leve e grave. J Vasc Bras. 2009;8(2):143-7. http://dx.doi.org/10.1590/ S1677-54492009000200008.

2. Robertson L, Yeoh SE, Kolbach DN. Non-pharmacological interventions for preventing venous insuficiency in a standing worker population. Cochrane Database Syst Rev. 2013;(10):CD006345. PMid:24127117.

3. Eberhardt RT, Raffetto JD. Chronic venous insufficiency. Circulation. 2014;130(4):333-46. http://dx.doi.org/10.1161/ CIRCULATIONAHA.113.006898. PMid:25047584.

4. Araujo DN, Ribeiro CT, Maciel AC, Bruno SS, Fregonezi GA, Dias FA. Physical exercise for the treatment of non-ulcerated chronic venous insufficiency. Cochrane Database Syst Rev. 2016;12(12):CD010637. http://dx.doi.org/10.1002/14651858. CD010637.pub2. PMid:27914110.

5. Leal FJ, Santos LMS, Couto RC, Moraes SGP, Silva TS, Santos WR. Tratamento fisioterapêutico vascular para a doença venosa crônica: artigo de revisão. J Vasc Bras. 2016;15(1):34-43. http:// dx.doi.org/10.1590/1677-5449.003215.

6. Silva GCC, Medeiros RJD, Oliveira LS, et al. Treinamento de sobrecarga muscular não afeta o diâmetro das principais veias dos membros inferiores em mulheres adultas com insuficiência venosa. Rev Bras Med Esporte. 2010;16(6):413-7. http://dx.doi. org/10.1590/S1517-86922010000600003.

7. Lurie F, Passman M, Meisner M, et al. The 2020 update of the CEAP classification system and reporting standards. J Vasc Surg Venous Lymphat Disord. 2020;8(3):342-52. http://dx.doi.org/10.1016/j. jvsv.2019.12.075. PMid:32113854. 
8. Bertochi T, Gomes RZ, Martins M. Mobilidade da articulação talocrural como fator preditor no prognóstico de cicatrização em portadores de insuficiência venosa crônica com úlcera venosa. J Vasc Bras. 2019;18:e20180133. http://dx.doi.org/10.1590/1677-5449.180133. PMid:31360156

9. Medeiros J, Mansilha A. Estratégia terapêutica na doença venosa crônica. Angiol Cir Vasc. 2012;8(3):110-2.

10. Aquino MAS, Paixão LCV, Leal FJ, Couto RC. Análise dos efeitos dos exercícios aquáticos na qualidade de vida de indivíduos com doença venosa crônica. J Vasc Bras. 2016;15(1):27-33. http://dx.doi. org/10.1590/1677-5449.005115.

11. Ercan S, Çetin C, Yavuz T, Demir HM, Atalay YB. Effects of isokinetic calf muscle exercise program on muscle strength and venous function in patients with chronic venous insufficiency. Phlebology. 2018;33(4):261-6. PMid:28954574.

12. Leal FJ, Couto RC, Silva TP, Tenório VO. Fisioterapia vascular no tratamento da doença venosa crônica. J Vasc Bras. 2015;14(3):22430. http://dx.doi.org/10.1590/1677-5449.0029.

13. Kravtsov PF, Katorkin SA, Volkovoy VV, Sizonenko YV. The influence of the training of the muscular component of the musculo-venous pump in the lower extremities on the clinical course of varicose vein disease. Vopr Kurortol Fizioter Lech Fiz Kult. 2016;93(6):33-6. http://dx.doi.org/10.17116/kurort2016633-36. PMid:28091490.

14. Hartmann BR, Drews B, Kayser T. Physical therapy improves venous hemodynamics in cases of primary varicosity: results of a controlled study. Angiology. 1997;48(2):157-62. http://dx.doi. org/10.1177/000331979704800209. PMid:9040271.

15. Caggiati A, Maeseneer M, Cavezzi A, Mosti G, Morrison N. Rehabilitation of patients with venous diseases of the lower limbs: State of the art. Phlebology. 2018;33(10):663-71. http://dx.doi. org/10.1177/0268355518754463. PMid:29361892.

16. Orr L, Klement KA, McCrossin L, et al. A systematic review and meta-analysis of exercise intervention for the treatment of calf muscle pump impairment in individuals with chronic venous insufficiency. Ostomy Wound Manage. 2017;63(8):30-43. http:// dx.doi.org/10.25270/owm.2017.08.3043. PMid:28873064.

17. Shamseer $L$, Moher D, Clarke $M$, et al. Preferred reporting items for systematic review and meta-analysis protocols (PRISMA-P) 2015: elaboration and explanation. BMJ. 2015;350(1):g7647. http:// dx.doi.org/10.1136/bmj.g7647. PMid:25555855.

18. Jull A, Parag V, Walker N, Maddison R, Kerse N, Johns T. The prepare pilot RCT of home-based progressive resistance exercises for venous leg ulcers. J Wound Care. 2009;18(12):497-503. http:// dx.doi.org/10.12968/jowc.2009.18.12.45606. PMid:20081574.

19. Szewczyk MT, Jawień A, Cwajda-Białasik J, Cierzniakowska K, Mościcka P, Hancke E. Randomized study assessing the influence of supervised exercises on ankle joint mobility in patients with venous leg ulcerations. Arch Med Sci. 2010;6(6):956-63. http:// dx.doi.org/10.5114/aoms.2010.19308. PMid:22427773.

20. O'Brien J, Edwards H, Stewart I, Gibbs H. A home-based progressive resistance exercise programme for patients with venous leg ulcers: a feasibility study. Int Wound J. 2013;10(4):389-96. http://dx.doi. org/10.1111/j.1742-481X.2012.00995.x. PMid:22697811.

21. Padberg FT Jr, Johnston MV, Sisto SA. Structured exercise improves calf muscle pump function in chronic venous insufficiency: a randomized trial. J Vasc Surg. 2004;39(1):79-87. http://dx.doi. org/10.1016/j.jvs.2003.09.036. PMid:14718821.

22. Yang D, Vandongen YK, Stacey MC. Effect of exercise on calf muscle pump function in patients with chronic venous disease. Br J Surg. 1999;86(3):338-41. http://dx.doi.org/10.1046/j.13652168.1999.00993.x. PMid:10201775.
23. Elsisi HFEM, Mahmoud TH, Serry ZMH, Rahmy AF, Osman NMM. Effect of strengthening exercise versus intermittent pneumatic compression device to calf muscle on blood flow in patients with varicose Veins. Biosci Res. 2019;16(2):2360-8.

24. Zajkowski PJ, Draper T, Bloom J, Henke PK, Wakefield TW. Exercise with compression stockings improves reflux in patients with mild chronic venous insufficiency. Phlebology. 2006;21(2):100-4. http:// dx.doi.org/10.1258/026835506777304764.

25. van Uden CJ, van der Vleuten CJ, Kooloos JG, Haenen JH, Wollersheim H. Gait and calf muscle endurance in patients with chronic venous insufficiency. Clin Rehabil. 2005;19(3):339-44. http://dx.doi.org/10.1191/0269215505cr809oa. PMid:15859535.

26. Orsted HL, Radke L, Gorst R. The impact of musculoskeletal changes on the dynamics of the calf muscle pump. Ostomy Wound Manage. 2001;47(10):18-24. PMid:11890075.

27. Qiao T, Liu C, Ran F. The impact of gastrocnemius muscle cell changes in chronic venous insufficiency. Eur I Vasc Endovasc Surg. 2005;30(4):430-6. http://dx.doi.org/10.1016/j.ejvs.2005.05.017. PMid:16009580.

28. Timi JR, Belczak SQ, Futigami AY, Pradella FM. A anquilose tíbiotársica e sua importância na insuficiência venosa crônica. J Vasc Bras. 2009;8(3):214-8. http://dx.doi.org/10.1590/S1677-54492009000300005.

29. Back TL, Padberg FT Jr, Araki CT, Thompson PN, Hobson RW 2nd. Limited range of motion is a significant factor in venous ulceration. J Vasc Surg. 1995;22(5):519-23. http://dx.doi.org/10.1016/S07415214(95)70030-7. PMid:7494349.

30. Catarinella FS, Nieman FH, Wittens $\mathrm{CH}$. An overview of the most commonly used venous quality of life and clinical outcome measurements. J Vasc Surg Venous Lymphat Disord. 2015;3(3):33340. http://dx.doi.org/10.1016/j.jvsv.2014.09.003. PMid:26992316.

Correspondence Henrique Silveira Costa Universidade Federal dos Vales do Jequitinhonha e Mucuri - UFVJM Rodovia MGT 367, Km 583, 5000 - Alto da Jacuba CEP 39100-000 - Diamantina (MG), Brasil Tel.: +55 (38) 3532-1200 E-mail: henriquesilveira@yahoo.com.br

Author information KLSS and EABF - Physical therapists; Residents, Programa de Residência em Fisioterapia na Saúde Coletiva, Universidade Federal dos Vales do Jequitinhonha e Mucuri (UFVJM).

CPL - Fisioterapia student, Universidade Federal dos Vales do Jequitinhonha e Mucuri (UFVJM).

MVAV - Cardiologist; Assistant professor, Faculdade de Medicina, Universidade Federal dos Vales do Jequitinhonha e Mucuri (UFVJM); Postgraduate student, Programa de Pós-graduação em Reabilitação e Desempenho Funcional, UFVJM.

VPL, PHSF and HSC - Adjunct professors, Departamento de Fisioterapia, Universidade Federal dos Vales do Jequitinhonha e Mucuri (UFVJM); Professors, Programa de Pós-graduação em Reabilitação e Desempenho Funcional, UFVJM.

Author contributions Conception and design: HSC, VPL, PHSF, CPL Analysis and interpretation: KLSS, EABF, CPL Data collection: KLSS, CPL, HSC Writing the article: KLSS, EABF, MVAV Critical revision of the article: HSC, VPL, PHSF Final approval of the article*: KLSS, EABF, CPL, MVAV, VPL, PHSF, HSC Statistical analysis: N/A. Overall responsibility: HSC

*All authors have read and approved of the final version of the article submitted to J Vasc Bras. 